\title{
大学帰属感尺度（SUM-6）の開発
}

\author{
○奥田 亮・川上正浩・坂田浩之・佐久田祐子 \\ (大阪樟蔭女子大学) \\ キーワード : 大学への帰属感, 尺度, 大学への適応
}

\begin{abstract}
Development of Sense of University Membership Scale (SUM-6)
Akira OKUDA ${ }^{1}$, Masahiro KAWAKAMI ${ }^{1}$, Hiroyuki SAKATA ${ }^{1}$ and Yuko SAKUTA ${ }^{1}$

('Osaka Shoin Women's University)

Key Words: sense of university membership, scales, adaptation to university
\end{abstract}

\begin{abstract}
目的
リスクのある学生にとって, 学校への帰属意識やその一員 であるという意識が，学校への参加やリテンションにおける 潜在的な決定因であるとされている（Goodenow，1993）。筆 者らも, 大学生活における学生の充実感や満足感に関する研 究（例えば坂田他, 2006, 佐久田他, 2007) を進める中で, 大学への帰属感が大学生活に対する充実感を高めることと関 連する（佐久田他，2008）という知見を得た。そこで，大学 への帰属感を高める教育プログラムを開発し(川上他, 2009, 等), 帰属感尺度 (川上他, 2009) と大学生活充実度尺度 (川 上他，2005；後に奥田他，2010）を用いて，その効果を測定 してきた（川上他，2016, 等)。また, 学年進行に伴う帰属感 や大学生活充実感の推移の調査も継続的に行ってきた。その 中で，筆者らは大学生活充実度尺度（SoULS-20）の信頼性お よび妥当性を検討し開発を行った（佐久田他，投稿中）。これ に伴い, 上記の一連の研究に用いられた帰属感尺度について も再検討を行うこととした。

帰属感の測定に関しては，Goodenow（1993）の Psychological Sense of School Membership (PSSM) scale が あるが, これは大学生を対象として作成されたものではなく, 項目数も比較的多い。また, 帰属感尺度は単独で用いるより も，不適応感などの他の指標と共に用いることで，活用の幅 が広がると考えられる。そのため, 調査対象者の負担軽減と いう観点から, 本研究では, 大学生を対象とした項目数の少 ない施行の簡便な尺度を新たに作成することを目的とする。 すなわち, 上記の一連の研究で用いられた帰属感尺度の 14 項 目を再精査し, 厳選された項目からなる大学帰属感尺度の開 発を行う。
\end{abstract}

\section{方 法}

調査対象者 大学生 626 名（男性 131 名, 女性 494 名, 性別 不明 1 名, 平均年齢 20.3 歳, 標準偏差 1.30) を対象とした。 質問紙の構成 （1）帰属感尺度:川上他（2009）の作成した尺 度（14 項目 5 件法）を用いた。(2) SoULS-20 : 大学生活の充 実度を測定する尺度（佐久田他，投稿中；20 項目 5 件法）を 用いた。

手続き 大学の授業時間内に集団法で質問紙を実施した。

\section{結 果}

帰属感尺度（川上他, 2009) の 14 項目について, 最尤法を 用いた因子分析を行った。因子負荷量の低い項目を除外しな がら繰り返し因子分析を行ったところ，1 因子構造であると いう結果が得られた。

次に項目数を減らす目的から, 因子負荷量の高さ, 分布の 尖度および歪度の絶対值の小ささ, 項目削除時の $\alpha$ 係数の高 さを考慮に入れながら, 最終的に 6 項目を尺度項目の候補と して残した。この 6 項目について, 再度最尤法による因子分
析を行ったところ, 改めて 1 因子構造であることが確認され た $(\alpha=.93)$ 。

そこで, この 6 項目を「大学帰属感尺度 (Sense of University Membership scale ; 6 items : SUM-6)」と命名し, Amos を用いた確認的因子分析を行った。その結果，適合度 指標は $\chi^{2}=46.96, d f=9, p<.001, \mathrm{GFI}=.98, \mathrm{AGFI}=.94$, RMSEA = .08, AIC = 70.96 であった（Table1）。

次に, SUM-6 の平均值を尺度得点とし, SoULS-20（佐久 田他, 投稿中）の 4 下位尺度得点との相関係数を算出した (Table2)。その結果, SUM-6 の得点と SoULS-20 の各下位 尺度との間に $0.1 \%$ 水準で有意な正の相関が認められた。中で も「学業満足」「大学へのコミットメント」「交友満足」との 関係は比較的強いことが明らかにされた。

比較のために, 14 項目の帰属感尺度（川上他，2009）と SoULS-20 の各下位尺度との相関係数も算出した（Table2）。

\section{考 察}

帰属感尺度（川上他，2009）より抜粋した 6 項目の $\alpha$ 係数 が高い值を示したこと，また確認的因子分析の結果から高い モデル適合度が得られたことより, SUM-6 の信頼性は十分高 いと言える。また, 大学生活充実度尺度のうち, 学業, 交友 関係, 大学へのコミットメントという, 帰属感に規定される 可能性が高い要因との相関が示されたこと, その数值は川上 他（2009）による 14 項目の帰属感尺度の相関とほぼ変わら ない值であることから, 妥当性についても十分認められたと 言える。

今後の課題として, この SUM-6 を用いて, 実際の大学生 活の適応に関わる諸指標（学業成績, 課外活動の状況や退学 等）と大学への帰属感がどのように関連するのかを調査・分 析し, 尺度の実用性について検討することが挙げられる。

Table1 SUM-6 の確認的因子分析結果

標準化推定値

$\begin{array}{ll}\text { この学科に愛着がある } & .85 \\ \text { この学科に誇りを持っている } & .82 \\ \text { この学科が自分の居場所だと思える } & .90 \\ \text { この学科にいる自分が好きだ } & .87 \\ \text { この学科の一員であると感じる } & .77 \\ \text { この学科に入ってよかった } & .77\end{array}$

Table2 SoULS-20 各下位尺度と SUM-6 の相関

\begin{tabular}{ccccc}
\hline & \multicolumn{4}{c}{ SoULS-20下位尺度 } \\
\cline { 2 - 5 } & $\begin{array}{c}\text { 大学への } \\
\text { コミットメント }\end{array}$ & 交友満足 & 学業満足 & 不安のなさ \\
\hline SUM-6 & .54 & .48 & .64 & .30 \\
帰属感尺度(14項目) & .56 & .54 & .68 & .31 \\
\hline
\end{tabular}

